\title{
Effects of Non-Conventional Substrate and NPK Fertilizer on Cassava Plantlets Acclimatization for Plant Material Production
}

\author{
Gilles Habib Todjro Cacaï, Corneille Ahanhanzo, Dèwanou Kant David Ahoya, \\ Serge Sètondji Houédjissin, Jerome Anani Houngue
}

Central Laboratory of Plant Biotechnology and Plant Breeding, Department of Genetics and Biotechnology, Faculty of Science and Technology, University of Abomey-Calavi, Cotonou, Benin

Email: *caghat@yahoo.fr

How to cite this paper: Cacaï, G.H.T., Ahanhanzo, C., Ahoya, D.K.D., Houédjissin, S.S. and Houngue, J.A. (2021) Effects of Non-Conventional Substrate and NPK Fertilizer on Cassava Plantlets Acclimatization for Plant Material Production. Agricultural Sciences, 12, 1058-1069. https://doi.org/10.4236/as.2021.1210068

Received: August 15, 2021

Accepted: October 9, 2021

Published: October 12, 2021

Copyright $\odot 2021$ by author(s) and Scientific Research Publishing Inc. This work is licensed under the Creative Commons Attribution International License (CC BY 4.0).

http://creativecommons.org/licenses/by/4.0/

(c) (i) Open Access

\begin{abstract}
The adaptation of cassava plantlets to natural conditions remains the main obstacle in the process of free virus plantlets production. In this study, cassava plantlets acclimatization was assessed by pre-acclimatization, height of acclimated plantlets, substrate, and nutrient watering solution. The results revealed that pre-acclimatization gave a high survival rate (61.9\%) whereas the direct tunnel acclimatization was conducted to low rate $(27.31 \%)$ of plantlets. Furthermore, the height of plantlets influenced significantly $(\mathrm{p}<0.05)$ their survival rate with best survival rate observed on plantlet height from $1 \mathrm{~cm}$ to $5 \mathrm{~cm}$. There was no significant difference between the substrates used and watering solutions. However, the Sawdust substrate gave a high survival rate (46.67\%) and better phylogenesis (1.8) in the variety RB 89509. Likewise, plantlets treated with NPK nutrient watering solutions (20-10-10) had a better survival rate $(48.57 \%)$, better phylogenesis (2.125) with the variety $\mathrm{RB}$ 89509 and better growth in height $(1.18 \mathrm{~cm})$ with the variety BF92/0267. These findings constitute a database for the establishment of the technical itinerary for the acclimatization of cassava plantlets.
\end{abstract}

\section{Keywords}

Manihot esculenta, Plantlets, Pre-Acclimatization, Substrates, Nutrient Solution, NPK

\section{Introduction}

Cassava is cultivated for its carbohydrate-rich roots, and leaves which constitute an inexpensive source of leafy vegetables rich in protein and vitamins [1] [2]. It 
is tolerant to harsh climatic conditions with minimum fertilizer for its production so it is a subsistence crop for over a milliard people in over 105 tropical and subtropical countries [3], thus ensuring the food security of many households in tropics [4] [5]. In Benin, it is cultivated in all agro-ecological zones by more than $70 \%$ of farmers and consumed by more than $50 \%$ of the population [6]. Furthermore, it contributes to the diversification of farmers' income. Considering cuttings usually obtained from neighboring fields or from the previous season, huge yield reductions due to an expansion of viral diseases were noted [7] [8]. It is one of the main causes of viral diseases propagation such as "Cassava Mosaic Disease" (CMD) and "Cassava Brown Streak Disease" (CBSD) [9]. With the constraint of non-availability free virus planting material, in vitro culture techniques have been developed to produce free virus planting material of cassava [10]. After meristem culture and micropropagation of some cassava varieties [11], the seedlings were acclimatized without taking into account the graduation conditions in acclimatization process, and other environmental and intrinsic factors in plantlets [12]. In fact, the nutrient watering solutions, relative humidity and temperature constitute important factors that determine the acclimatization process [13] [14]. Moreover, the effect of substrates is very decisive in the acclimatization success [15] [16] but few have discussed the use of local products including palm fibers and sawdust instead of peat and vermiculite. Likewise, different combinations of NPK fertilizers have been used successfully during acclimatization of cassava [17], and no research has documented the NPK fertilizers available for food crop. According to their height not considered in laboratory conditions, plantlets are sometimes very fragile and little adaptable to greenhouse or natural conditions with losses ranging up to 90\% [16]. Research undertook on acclimatization technique improvement is a challenge because, in addition to the strong thermal contrast between the greenhouse and the tissue culture conditions, the fertilizers used (peat and vermiculites) remain little available to farmers. That is the context the present work aims to optimize the conditions for successful acclimatization by considering environmental factors and healthy planting material, local substratum and NPK fertilizer in watering in order to renew the plant material existing in a peasant environment.

\section{Materials and Methods}

\subsection{Plant Material Origins}

The plant material was constituted of seven cassava varieties plantlets RB 89509, Atiwè, ATI, OKI, Dossi, Somity (local varieties from Benin) and BF92/0267 variety from Burkina-Faso. These varieties were included in the WAVE (Central and West African Virus Epidemiology) germplasm and theirs plantlets were produced at the Central Laboratory of Plant Biotechnology and Plant Breeding of the University of Abomey-Calavi in Benin (LCBVAP/UAC). 


\subsection{Calibration of Plantlets and Pre-Acclimatization}

Cassava plantlets with good root system, two nodes at least, and a minimum of three leaves were gently removed from the growing media. They were then calibrated according to their length $(\mathrm{cm})$ in five modalities: [1 - 5], ]5 - 10], ]10 15], and ]15 - 20], and after sown in the pots containing various substrates.

\subsection{Substrates and Watering Solutions}

Substrates were obtained by mixing compost, potting soil, sawdust and palm kernel fibers with distilled water (Table 1 ) and then sterilized in the autoclave at $121^{\circ} \mathrm{C}$ for $20 \mathrm{~min}$ [18]. This was followed by cooling for one hour and then potting in pots $(8.6 \mathrm{~cm}$ in diameter and $5.3 \mathrm{~cm}$ in height), pierced with 4 holes, washed and disinfected in bleach for $24 \mathrm{~h}$. A batch of seeded pots was placed directly in a tunnel where average internal temperature varies between $27.32^{\circ} \mathrm{C}$ and $28.91^{\circ} \mathrm{C}$ and the relative humidity varies between $88.38 \%$ and $99.98 \%$. The second batch was in an air-conditioned room with an internal temperature of $25^{\circ} \mathrm{C}$ and a relative humidity of $95 \%$ for seven days before being transferred to tunnel for five weeks. This humidity was kept saturated by regular sprinkling of water.

As concern the watering, the shive solution [12] control solution (SN1), and the NPK fertilizer solutions composed of 20-10-10 (SN2); 13-17-17 (SN3) constituting a modified combination derive from the recommended combination (10-52-10) for cassava acclimatization [17]. The nutrient watering solutions were obtained by diluting $2 \mathrm{~g}$ of fertilizer in $1 \mathrm{~L}$ of water and applied at $80 \mathrm{ml}$ per pot [19] immediately after transplanting into the substrates and once a week for the six weeks of the experiment.

\subsection{Experimental Set-Up and Data Analysis}

The experimental set-up was a random block made up of three rows of plastic pots. Each row representing a watering solution consists of three different types of substrate, the seven varieties with four repetitions; making 84 pots per row for a total of 252 pots for the three rows. Thus, each acclimatization condition (tunnel and air-conditioned chamber + tunnel) was made up of 252 pots, for a total of 504 pots for the conduct of the entire experiment. The data providing information on the survival or not of tissue culture plants under pre-acclimatization conditions were subjected to a binary logistic regression. A generalized linear regression model was applied in order to determine the relationship between the

Table 1. Acclimatisation substrates.

\begin{tabular}{ccc}
\hline Codifications & Substrates & Proportion \\
\hline S1 & Compost + Potting soil (Control) & $2: 1$ \\
S2 & Compost + Potting soil + Sawdust & $2: 1: 1$ \\
S3 & Compost + Potting soil + Palm fibre & $2: 1: 1$ \\
\hline
\end{tabular}

$\mathrm{S}=$ Substrate 
number of leaves and the substrates on the one hand and the nutrient watering solutions on the other. The height parameter of the plantlets was subjected to an analysis of variance (ANOVA) to reveal the differences between the treatments. Duncan's test was applied for treatments significant at the 5\% level. Data obtained were analyzed using XLSTAT version 14 software.

\section{Results}

\subsection{Effects of Pre-Acclimatization on Plantlets Survival}

The chi-square test showed a highly significant difference $(\mathrm{p}<0.0001)$ in the acclimatization processes. Also, varieties and the Pregnant $\times$ Variety interaction had a highly significant influence $(\mathrm{p}<0.0001)$ on plantlet survival. Under tunnel, the rate of survival varied from $24.44 \%$ (ATI) to $37.78 \%$ (Atiwè) against $44.44 \%$ (ATI) to $77.78 \%$ (OKI) under acclimatization conditions (Table 2, Figure 1).

Table 2. Binary regression of acclimatization process on plantlet survival.

\begin{tabular}{cccccc}
\hline Source & DDL & $\mathrm{Khi}^{2}(\mathrm{Wald})$ & $\mathrm{Pr}>\mathrm{Wald}$ & $\mathrm{Khi}^{2}(\mathrm{LR})$ & $\mathrm{Pr}>\mathrm{LR}$ \\
\hline Enclosures & 1 & 131.988 & $<0.0001$ & 35.37 & $<0.0001^{\star * *}$ \\
Varieties & 6 & 14.04 & 0.0292 & 14.262 & $0.0001^{\star * *}$ \\
Enclosures $\times$ Varieties & 6 & 26.646 & 0.0002 & 16.598 & $<0.0001^{\star * *}$ \\
\hline
\end{tabular}

${ }^{* *}=$ very highly significant difference $(\mathrm{p}<0.0001)$; DDL: degree of freedom, Pr: probability.

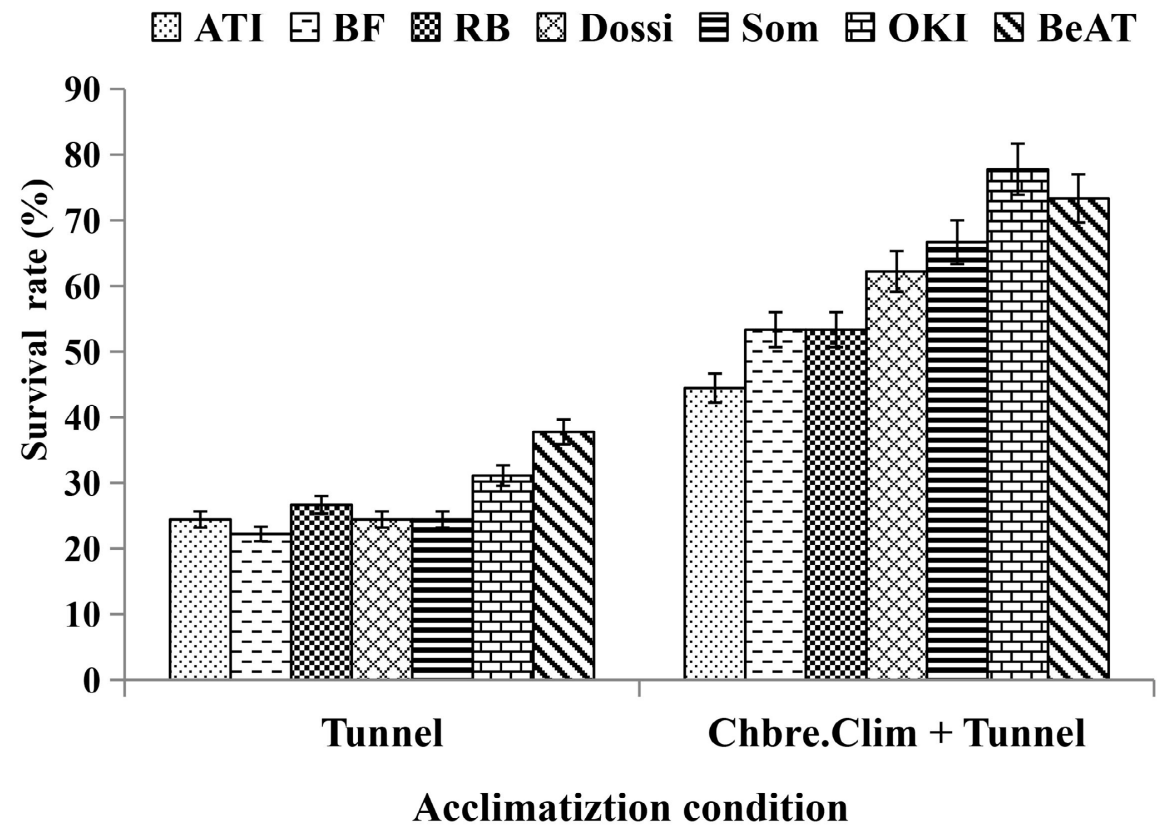

Figure 1. Variation of the survival rate of seven cassava plantlets varieties by acclimatization condition.

\subsection{Effects of the Height on Plantlet Survival}

The Chi-square test revealed a highly significant influence $(\mathrm{p}=0.023)$ within a 
height of different survival plantlet. However, the interaction between varieties and the variety $\times$ Height class interaction had a very high influence $(\mathrm{p}<0.0001)$ on survival rate acclimatization (Table 3 ). All varieties with a stem length between 1 and $5 \mathrm{~cm}$ exhibited a survival rate from $40 \%$ to $70 \%$; but those with a stem length between 5 and $10 \mathrm{~cm}$ exhibited a survival rate ranging from $20 \%$ to $53 \%$. Plantlets with stem length classed between ]10 - 15] cm, had a survival rate close to zero. However, with the class ]15 - 20], the varieties Dossi and BF exhibited respectively $50 \%$ and $100 \%$ of survival rates (Figure 2 ).

\subsection{Effects of Substrates on Survival and Growth of the Plantlets}

The results indicated that the survival rate of acclimatized plantlets was not influenced by the substrates $(p>0.05)$ (Table 4). In addition, genotype and the interaction genotypes $\times$ substrates had a significant influence on the survival rate $(\mathrm{p}=0.003$ ). This survival rate varied from $33.33 \%$ (ATI) to $56.67 \%$ (OKI) on substrate S1; from $32.67 \%$ (BF92/0267) to $60 \%$ (Atiwè) on the S2 substrate and from $30 \%$ (RB 89509) to $63.33 \%$ (Atiwè) on the $\mathrm{S} 3$ substrate (Figure 3).

The number of leaves emitted is not influenced by either substrate or the substrate $\times$ variety interaction. On the other hand, it is significantly influenced by

Table 3. Binary regression of the survival plantlets height on acclimatization.

\begin{tabular}{cccccc}
\hline Source & $\mathrm{DDL}$ & $\mathrm{Khi}^{2}($ Wald $)$ & $\mathrm{Pr}>$ Wald & $\mathrm{Khi}^{2}(\mathrm{LR})$ & $\mathrm{Pr}>\mathrm{LR}$ \\
\hline Height Class & 3 & 16.821 & 0.0008 & 17.299 & $0.023^{*}$ \\
Varieties & 6 & 52.351 & $<0.0001$ & 24.199 & $0.001^{\star *}$ \\
Varieties $\times$.Height Class & 13 & 52.283 & $<0.0001$ & 34.800 & $<0.0001^{* * *}$ \\
\hline
\end{tabular}

${ }^{*}=$ significant difference $(\mathrm{p}<0.05),{ }^{* *}=$ highly significant difference $(\mathrm{p}<0.01) ;{ }^{* *}=$ very highly significant difference $(\mathrm{p}<0.001)$ DDL: degree of freedom, Pr: probability; Class. Ht: height class.

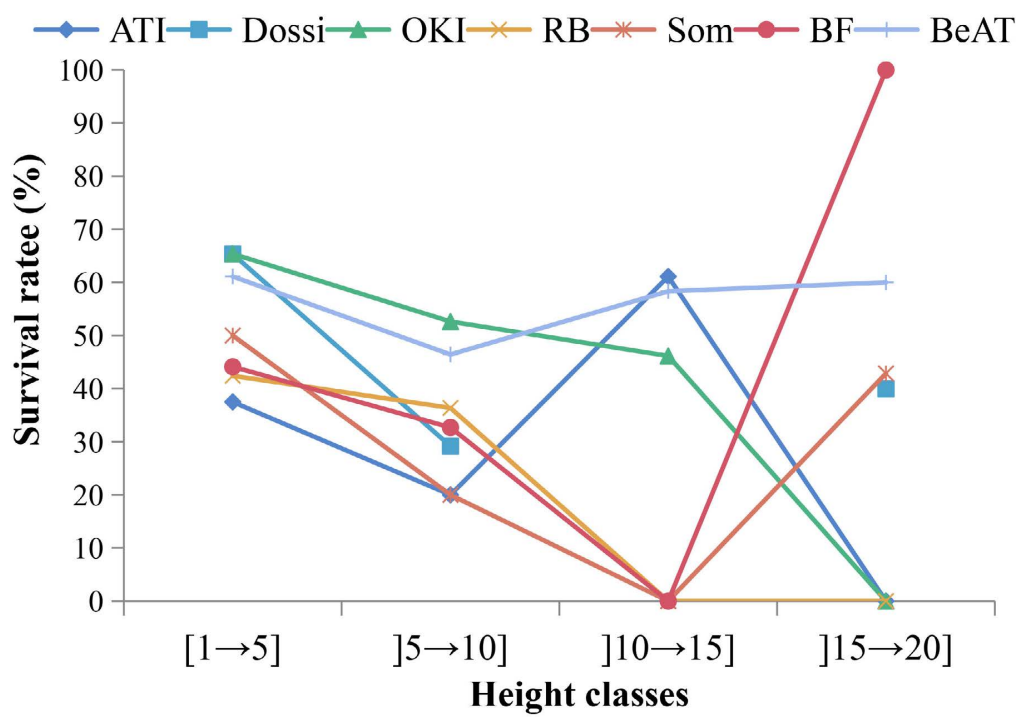

Figure 2. Interaction between plantlets from the seven cassava varieties and the height classes. 
Table 4. Binary regression of the substrates on the plantlets survival.

\begin{tabular}{cccccc}
\hline Source & $\mathrm{DDL}$ & $\mathrm{Khi}^{2}(\mathrm{Wald})$ & $\mathrm{Pr}>$ Wald & $\mathrm{Khi}^{2}(\mathrm{LR})$ & $\mathrm{Pr}>\mathrm{LR}$ \\
\hline Substrates & 2 & 0.6682 & 0.7160 & 0.667 & $0.414 \mathrm{NS}$ \\
Varieties & 6 & 19.775 & 0.0030 & 8.951 & $0.003^{* *}$ \\
Varieties $\times$ substrates & 12 & 12.4806 & 0.4079 & 7.0961 & $0.008^{* *}$ \\
\hline
\end{tabular}

NS = non-significant difference; ${ }^{*}=$ highly significant difference $(\mathrm{p}<0.01)$; DDL: degree of freedom, Pr: probability.
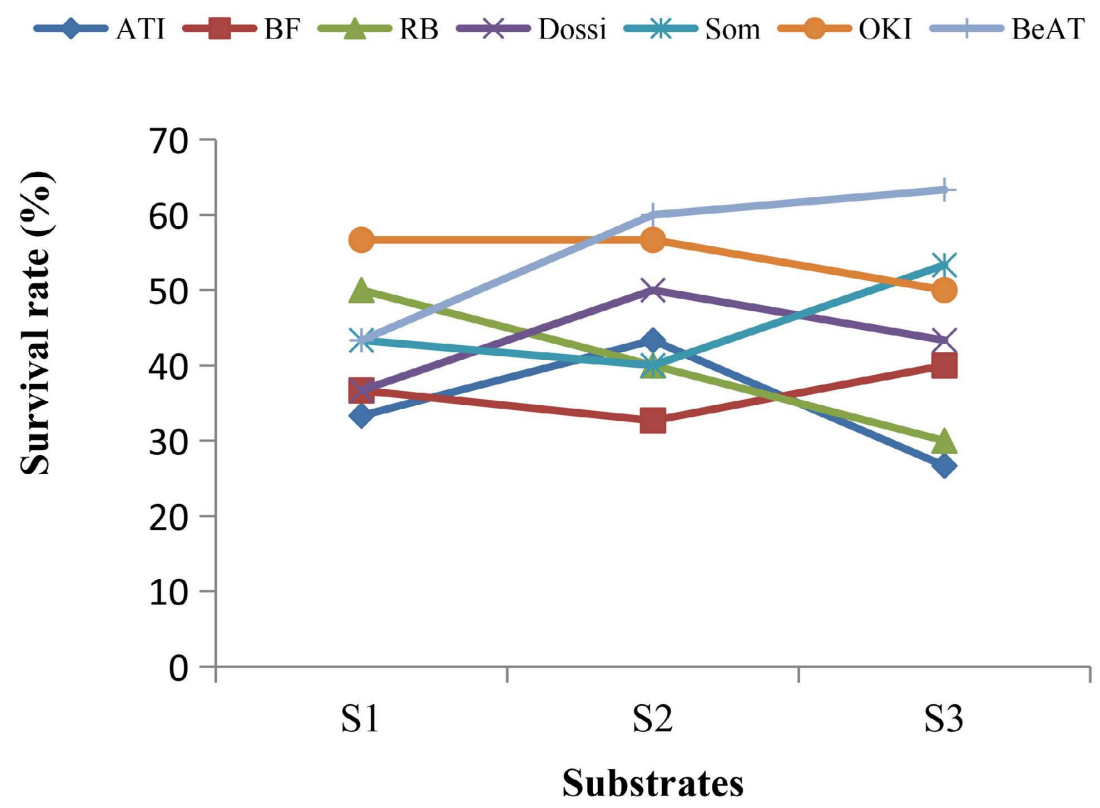

Figure 3. Interaction between plantlets from seven varieties of cassava and substrates.

the variety $(\mathrm{p}<0.004)$. The best phylogenesis was observed in RB89509 variety with 1.87 leaves on substrate S2. Furthermore, the coefficient of determination is low $\mathrm{R}^{2}(23.84 \%)<50 \%$ (Table 5).

Likewise, growth in height was very significantly influenced by cassava genotypes $(\mathrm{p}<0.0001)$, substrate and substrate $\times$ variety interaction had no influence on height growth. Thus, the BF92/0267 variety has a greater height whatever the substrate with values $0.90 \mathrm{~cm}, 1.2 \mathrm{~cm}$ and $1.13 \mathrm{~cm}$ respectively on the substrates $\mathrm{S} 1, \mathrm{~S} 2$ and S3. The lowest height gain was obtained in local varieties OKI (0.06 $\mathrm{cm})$ on substrate $\mathrm{S} 1$ and Dossi $(0.05 \mathrm{~cm})$ on substrate $\mathrm{S} 3$. In addition, it should be noted that the coefficient of determination is high $\mathrm{R}^{2}(\%)>50$ (Table 5).

\subsection{Effect of Watering Solution on Plantlet Survival and Growth}

The Chi-square Test showed no significant difference $(\mathrm{p}>0.05)$ between the watering nutrient solutions on the survival rate on cassava plantlets (Table 6). However, the varieties and the variety $\times$ nutrient solution interaction had a highly significant effect on the survival rate of plantlets $(\mathrm{p}<0.05)$. The survival rate per watering nutrient solution varied from $26.67 \%$ (BF92/0267) to $53.33 \%$ 
Table 5. Variation of the average number of leaves emitted and the height growth of plantlets by variety under the effect of substrates.

\begin{tabular}{|c|c|c|c|}
\hline Substrates & Varieties & NbreM.F & Gain HT (cm) \\
\hline \multirow{7}{*}{ S2 } & ATI & $0.33 \mathrm{a}$ & $0.1 \mathrm{a}$ \\
\hline & OKI & $0.40 \mathrm{a}$ & $0.06 \mathrm{a}$ \\
\hline & Som & 1.00 & $0.25 \mathrm{a}$ \\
\hline & Dossi & $1.33 \mathrm{a}$ & $0.1 \mathrm{a}$ \\
\hline & $\mathrm{BF}$ & $1.20 \mathrm{a}$ & $0.92 \mathrm{a}$ \\
\hline & $\mathrm{RB}$ & $1.62 \mathrm{a}$ & $1.00 \mathrm{a}$ \\
\hline & BeAT & $1.67 \mathrm{a}$ & $0.13 a$ \\
\hline \multirow{7}{*}{$\mathrm{S} 2$} & ATI & $1.00 \mathrm{a}$ & $0.167 \mathrm{a}$ \\
\hline & OKI & $0.80 \mathrm{a}$ & $0.08 \mathrm{a}$ \\
\hline & Som & $1.00 \mathrm{a}$ & $0.47 \mathrm{a}$ \\
\hline & Dossi & $1.00 \mathrm{a}$ & $0.22 \mathrm{a}$ \\
\hline & $\mathrm{BF}$ & $1.20 \mathrm{a}$ & $1.20 \mathrm{a}$ \\
\hline & $\mathrm{RB}$ & $1.86 \mathrm{a}$ & $0.80 \mathrm{a}$ \\
\hline & BeAT & $1.17 \mathrm{a}$ & $0.20 \mathrm{a}$ \\
\hline \multirow{7}{*}{ S3 } & ATI & $1.00 \mathrm{a}$ & $0.10 \mathrm{a}$ \\
\hline & OKI & $1.25 \mathrm{a}$ & $0.12 \mathrm{a}$ \\
\hline & Som & $1.00 \mathrm{a}$ & $0,10 \mathrm{a}$ \\
\hline & Dossi & $1.25 \mathrm{a}$ & $0.05 \mathrm{a}$ \\
\hline & $\mathrm{BF}$ & $1.00 \mathrm{a}$ & $1.13 \mathrm{a}$ \\
\hline & $\mathrm{RB}$ & $1.75 \mathrm{a}$ & $1.20 \mathrm{a}$ \\
\hline & BeAT & $1.17 \mathrm{a}$ & $0.17 \mathrm{a}$ \\
\hline \multirow{4}{*}{$\mathrm{P}$-value } & $\mathrm{R}^{2}(\%)$ & 23.84 & 57.29 \\
\hline & Varieties & $0.004^{\star *}$ & $<0.0001^{\star * \star}$ \\
\hline & Substrates & $0.572 \mathrm{NS}$ & $0.757 \mathrm{NS}$ \\
\hline & Substrates $\times$ Varieties & $0.876 \mathrm{NS}$ & $0.946 \mathrm{NS}$ \\
\hline
\end{tabular}

NbreM. F: Average number of leaves; HT gain ( $\mathrm{cm}$ ): Height gain; The values followed by the same letter are not significantly different; NS $=$ non-significant difference; ${ }^{* *}=$ very highly significant difference $(\mathrm{p}<$ $0.001)$.

Table 6. Binary regression of watering nutrient solutions on plantlets survival.

\begin{tabular}{cccccc}
\hline Source & DDL & $\mathrm{Khi}^{2}($ Wald $)$ & $\mathrm{Pr}>$ Wald & $\mathrm{Khi}^{2}(\mathrm{LR})$ & $\mathrm{Pr}>\mathrm{LR}$ \\
\hline Solutions Nut. & 2 & 2.169 & 0.338 & 2.168 & $0.140 \mathrm{NS}$ \\
Varieties & 6 & 27.105 & 0.0001 & 12.049 & $0.0005^{* * *}$ \\
Varieties $\times$ Solutions Nut. & 12 & 18.118 & 0.1121 & 9.620 & $0.001^{* *}$ \\
\hline
\end{tabular}

$\mathrm{S}=$ not significant difference; ${ }^{*}=$ significant difference $(\mathrm{p}<0.05),{ }^{* *}=$ highly significant difference $(\mathrm{p}<$ $0.01)$; DDL: ${ }^{* *}=$ very highly significant difference $(\mathrm{p}<0.001)$; degree of freedom, Pr: probability; Nut. Nutrient solutions. 
(Atiwè) for SN1 solution; from 36.67\% (Somity) to 63.33\% (Atiwè) for SN2 solution, and from $30 \%$ (RB 89509) to $53.33 \%$ (OKI) for the SN3 solution (Figure 4).

\subsection{Effect of Nutrient Irrigation Solutions on the Survival Plantlets from the Seven Cassava Varieties during Acclimatization}

The nutrient solution and the nutrient solutions $\times$ varieties interaction showed no significant influence on the number of leaves emitted. The varieties presented a significant effect $(\mathrm{p}<0.05)$ on the emission of new leaves with a better phylogenesis observed on RB 89509 variety (2.13 leaves with SN2) and the lowest observed on OKI variety (0.33) using SN3 nutrient solution. Furthermore, the coefficient of determination is low $\mathrm{R}^{2}(30.57 \%)<50$ (Table 7).

Height growth was very significantly influenced by genotypes $(\mathrm{p}<0.0001)$ with coefficient of determination is high $\mathrm{R}^{2}(58.6 \%)>50$ ) (Table 7 ). The nutrient watering solution and the nutrient watering solution $\times$ variety interaction had no influence on height growth (Table 6). Plantlets of the variety BF92/0267 had a higher height regardless of the nutrient watering solution. Thus, the gain in height was $0.8 \mathrm{~cm}, 1.18 \mathrm{~cm}$ and $1.12 \mathrm{~cm}$ respectively for SN1, SN2 and SN3. The lowest height gains were obtained in local varieties OKI $(0 \mathrm{~cm}$ with $\mathrm{SN} 3)$, ATI (0.05 cm with SN3) and Sommity (0.025 cm with SN1).

\section{Discussion}

The response of cassava plantlets to acclimatization varied according to acclimatization conditions, height of plantlets, non-conventional substrate used, and nutrient watering solution. The survival rate obtained in pre-acclimatization

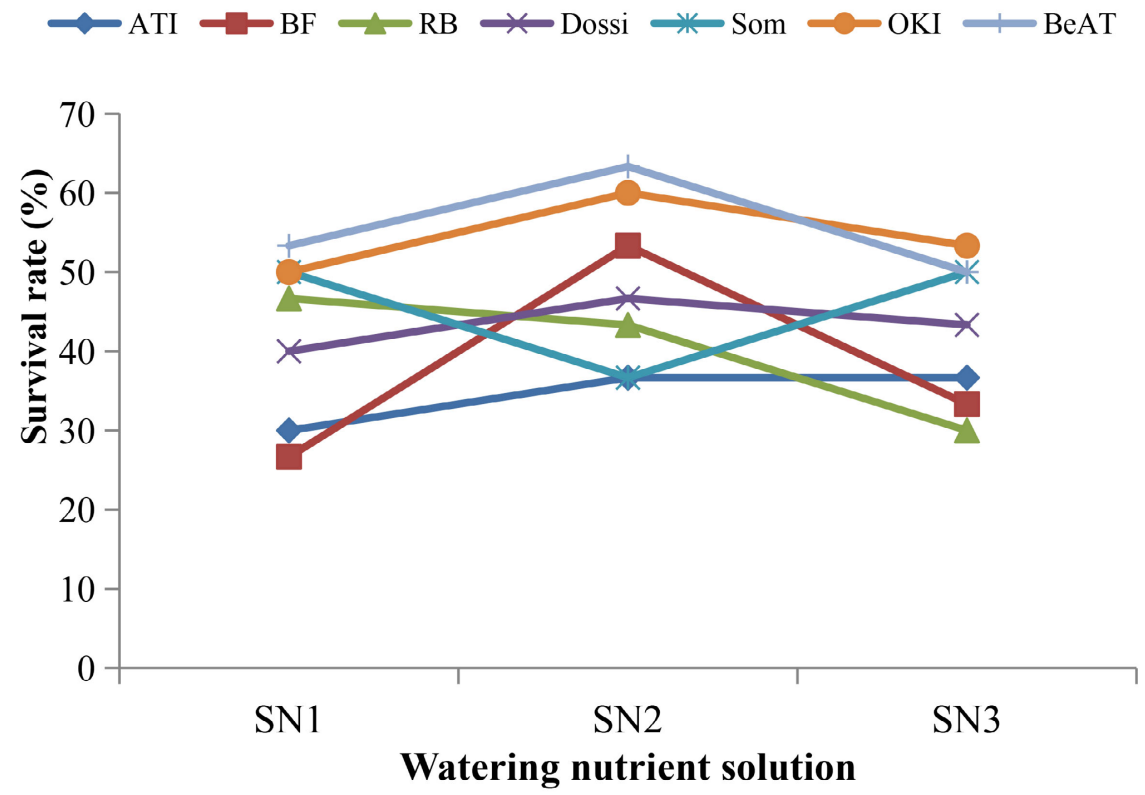

Figure 4. Interaction of seven cassava plantlets varieties with the watering nutrient solution. 
Table 7. Variation of the average leaf number and the height growth of plantlets per variety under the effect of watering nutrient solutions.

\begin{tabular}{|c|c|c|c|}
\hline Substrates & Varieties & NbreM.F & Gain HT. $(\mathrm{cm})$ \\
\hline \multirow{7}{*}{ SN1 } & ATI & $0.50 \mathrm{a}$ & $0.10 \mathrm{a}$ \\
\hline & OKI & $1.00 \mathrm{a}$ & $0.13 \mathrm{a}$ \\
\hline & Som & $1.50 \mathrm{a}$ & $0.03 \mathrm{a}$ \\
\hline & Dossi & $1.33 \mathrm{a}$ & $0.13 a$ \\
\hline & $\mathrm{BF}$ & $1.00 \mathrm{a}$ & $0.80 \mathrm{a}$ \\
\hline & $\mathrm{RB}$ & $1.38 \mathrm{a}$ & $0.78 \mathrm{a}$ \\
\hline & BeAT & $1.20 \mathrm{a}$ & $0.14 \mathrm{a}$ \\
\hline \multirow{7}{*}{$\mathrm{SN} 2$} & ATI & $0.75 \mathrm{a}$ & $0.18 \mathrm{a}$ \\
\hline & OKI & $1.20 \mathrm{a}$ & $0.16 \mathrm{a}$ \\
\hline & Som & $0.75 a$ & $0.28 \mathrm{a}$ \\
\hline & Dossi & $1.20 \mathrm{a}$ & $0.16 \mathrm{a}$ \\
\hline & $\mathrm{BF}$ & $1.18 \mathrm{a}$ & $1.18 \mathrm{a}$ \\
\hline & $\mathrm{RB}$ & $2.13 \mathrm{a}$ & $1.11 \mathrm{a}$ \\
\hline & BeAT & $1.50 \mathrm{a}$ & $0.20 \mathrm{a}$ \\
\hline \multirow{7}{*}{$\mathrm{SN} 3$} & ATI & $1.00 \mathrm{a}$ & $0.05 a$ \\
\hline & OKI & $0.33 a$ & $0 . \mathrm{a}$ \\
\hline & Som & $0.75 a$ & $0.53 \mathrm{a}$ \\
\hline & Dossi & $0.67 \mathrm{a}$ & $0.07 \mathrm{a}$ \\
\hline & $\mathrm{BF}$ & $1.60 \mathrm{a}$ & $1.12 \mathrm{a}$ \\
\hline & $\mathrm{RB}$ & $1.67 \mathrm{a}$ & $1.10 \mathrm{a}$ \\
\hline & BeAT & 1a & $0.18 \mathrm{a}$ \\
\hline \multirow{4}{*}{ P-value } & $\mathrm{R}^{2}(\%)$ & 30.57 & 58.6 \\
\hline & Varieties & $0.035^{\star}$ & $<0.0001^{* * *}$ \\
\hline & $\mathrm{SN}$. & $0.459 \mathrm{NS}$ & $0.326 \mathrm{NS}$ \\
\hline & SN. $\times$ Varieties & $0.389 \mathrm{NS}$ & $0.969 \mathrm{NS}$ \\
\hline
\end{tabular}

SN: Watering nutrient solution; NbreM.F: Average number of leaves; Values followed by the same letter are not significantly different; HT gain $(\mathrm{cm})$ : Height gain; NS = non-significant difference; * ${ }^{*}$ significant difference $(\mathrm{p}>5 \%) ;{ }^{\star *}=$ very highly significant difference $(\mathrm{p}<0.001)$.

condition (42.29\%) was clearly higher than that obtained by Cacaï et al. [12] directly under tunnel. Indeed, the passage of cassava plantlet through the artificial conditions of tissue culture (temperature: $25^{\circ} \mathrm{C}$ and humidity 100\%) to the tunnel conditions (temperature $28.4^{\circ} \mathrm{C}$ and humidity $90 \%$ ) could create a thermal shock and promote strong perspiration on plantlets, due to the opening of their stomata [20] and limiting their survival. In addition, Chandra et al. [21] have shown that direct transfer of plantlets to broad spectrum sunlight (4000 - 12,000 lux) and temperature $\left(26^{\circ} \mathrm{C}-36^{\circ} \mathrm{C}\right)$ can cause leaves carbonization and seedlings wilting. So, it is judicious to make a gradual transfer of plantlet during acclima- 
tization [18]. Thus, by maintaining in a humid tent for six weeks and gradual transfer of plantlet during the acclimatization allowed an adaptation to the conditions of the new environment.

These depending on the responses of varieties were not influenced by the substrate. Thus, compost and potting soil are common elements to all three substrates, sawdust and palm kernel fibers did not provide any significant improvement in the quality of the substrates. Also, we note the quality of the substrates used in water retention, promoting optimal growth of the root system and the development of plantlets [18].

The different nutrient watering solutions did not significantly impact the survival rate of plantlets. In fact, plantlets survive during the first days of acclimatization are related to the energy reserves accumulated in the roots in in vitro conditions, which was similar to the works of Aragon et al. [22] on the need of good system root for the removal of mineral elements. Genotype has significantly influenced the absorption elements from the watering solutions, which explains a better survival rate of the BeAT variety over other varieties regardless of the watering solution. Also, the effect of varieties and that of nutrient watering solutions could not be separated to explain the success of acclimatization. Finally, the coefficients of determination are low in explaining the effect of both substrates and nutrient solutions for leaf emission. Moreover, they are bred for the gain in height of plantlets acclimatized. It showed the gain in height best discriminates the respective effects of substrates and nutrient solutions for successful acclimatization, this revealed the effects of technological treatments on cassava nutrient composition [23].

\section{Conclusion}

From this study, it emerges that the pre-acclimatization of cassava plantlet to a temperature of $25^{\circ} \mathrm{C} \pm 1^{\circ} \mathrm{C}$ and humidity average of $90 \%$ for seven days before their passage through the tunnel improved the survival rate. In addition, plantlet height had a significant impact on the acclimatization success. For this factor, plantlet with a height from 1 to $5 \mathrm{~cm}$ was more apt to survive. It should be noted that the combination (Soil + Compost + Sawdust) on the one hand and the nutrient watering solutions of NPK fertilizer (20-10-10) on the other hand gave the best survival rate, phylogenesis and height growth.

\section{Acknowledgements}

This work was financially supported by the Bill and Melinda Gates foundation-funded WAVE (Central and West African Virus Epidemiology) programme. The authors acknowledge the European Union for additional financial assistance.

\section{Conflicts of Interest}

The authors declare no conflicts of interest regarding the publication of this paper. 


\section{References}

[1] Esuma, W., Rubaihayo, P., Pariyo, A., Kawuki, R., Wanjala, B., Nzuki, I. and Baguma, Y. (2012) Genetic Diversity of Provitamin A Cassava in Uganda. Journal of Plant Studies, 1, 60-71. https://doi.org/10.5539/jps.v1n1p60

[2] da Costa, T.R., Pedro Soares, V.F., Maria, C., Marta, Z.G., Giselly, F.L., da Silva, L.I. and Marcus, V.K. (2013) Genetic Diversity and Population Structure of Sweet Cassava Using Simple Sequence Repeat (SSR) Molecular Marker. African Journal of Biotechnology, 12, 1040-1048.

[3] Chetty, C., Rossin, C., Gruissem, W., Vanderschuren, H. and Rey, M. (2013) Empowering Biotechnology in Southern Africa: Establishment of a Robust Transformation Platform for the Production of Transgenic Industry-Preferred Cassava. $\mathrm{NeW}$ Biotechnology, 30, 136-143. https://doi.org/10.1016/j.nbt.2012.04.006

[4] Turyagyenda, L.F., Kizito, E.B., Ferguson, M.E., Baguma, Y., Harvey, J.W., Gibson, P., Wanjala, B.W. and Osiru, D.S.O. (2012) Genetic Diversity among Farmer-Preferred Cassava Landraces in Uganda. African Crop Science Journal, 20, 15-30.

[5] Rabbi, I.Y., Hamblin, M.T., Kumar, P.L., Gedil, M.A., Ikpan, A.S., Jannink, J.L. and Kulakow, P.A. (2014) High-Resolution Mapping of Resistance to Cassava Mosaic Geminiviruses in Cassava Using Genotyping-by-Sequencing and Its Implications for Breeding. Virus Research, 186, 87-96. https://doi.org/10.1016/j.virusres.2013.12.028

[6] Hongbete, F., Mestres, C., Akissoé, N., Pons, B., Hounhouigan, D.J., Cornet, D. and Mathurin, N.C. (2011) Effects of Cultivar and Harvesting Conditions (Age, Season) on the Texture and Taste of Boiled Cassava Roots. Food Chemistry, 126, 127-133. https://doi.org/10.1016/j.foodchem.2010.10.088

[7] Mahungu, N.M., Tata-Hangy, K.W., Bidiaka, S.M. and Frangoie, A. (2014) Multiplication de matériel de plantation de manioc et gestion des maladies et ravageurs. L'Institut International d'Agriculture Tropical, Ibadan, 5.

[8] Houngue, J.A., Pita, J.S., Cacaï, G.H.T., Zandjanakou-Tachin, M., Abidjo, E.A.E. and Ahanhanzo, C. (2018) Survey of Farmers' Knowledge of Cassava Mosaic Disease and Their Preferences for Cassava Cultivars in Three Agro-Ecological Zones in Benin. Journal of Ethnobiology and Ethnomedecine, 4, Article No. 29. https://doi.org/10.1186/s13002-018-0228-5

[9] Da Silva, R.M., Bandel, G. and Martins, P.S. (2003) Mating System in an Experimental Garden Composed of Cassava (Manihot esculenta Crantz) Ethnovarieties. Euphytica, 134, 127-135. https://doi.org/10.1023/B:EUPH.0000003644.60126.4a

[10] Nkaa, F., Ene-Obong, E., Taylor, N., Fauquet, C. and Mbanaso, E. (2013) Elimination of African Cassava Mosaic Virus (ACMV) and East African Cassava Mosaic Virus (EACMV) from Cassava (Manihot esculenta Crantz) cv. 'Nwugo' via Somatic Embryogenesis. American Journal of Biotechnology and Molecular Sciences, 3, 33-40.

[11] Cacaï, G.H.T., Adoukonou-Sagbadja, H., Kumulugui, B.S., Ovono, P.O., Houngue, J. and Ahanhanzo, C. (2013) Eradication of Cassava (Manihot esculenta) Mosaic Symptoms through Thermotherapy and Meristems Cultured in Vitro. International Journal of Agronomy and Plant Production, 4, 3697-3701.

[12] Cacaï, G.H.T., Noel, M.L., Nguema, N.P., Ondo, O.P., Agbangla, C. and Ahanhanzo, C. (2013) Effets de l'acclimatation sur le comportement en milieu reel de quelques varietes ameliorees de manioc (Manihot esculenta, crantz) cultivees au Benin. 
Journal de la Recherche Scientifique de P Université de Lomé, 15, 45-52.

[13] Pitoyo, A., Hani, M.R. and Endang, A.E. (2015) Application of Chitosan Spraying on Acclimatization Success of Tiger Orchid (Grammatophyllum scriptum) Plantlets. Nusantara Bioscience, 7, 185-191. https://doi.org/10.13057/nusbiosci/n070222

[14] da Silva, J.A.T., Hossain, M.M., Sharma, M., Dobránszki, J., Cardoso, J.C. and Zeng, S. (2017) Acclimatization of in Vitro-Derived Dendrobium. Horticultural Plant Journal, 3, 110-124. https://doi.org/10.1016/j.hpj.2017.07.009

[15] Youmbi, E. and Ngaha, D. (2004) Expression in vitro des capacités organogènes des bourgeons axillaires chez le bananier plantain (Musa spp.). Fruits, 59, 241-248. https://doi.org/10.1051/fruits:2004022

[16] Bonilla Morales, M.M., Sánchez Ordoñez, S.A. and Pachón García, J. (2015) Evaluation of Organic Substrates for Acclimatization and Hardening of Plantlets of Cassava (Manihot esculenta Crantz). Revista de Investigación Agraria y Ambiental, 6, 31-36.

[17] Ospina, P.B., Segovia, R.J. and Bedoya, A. (2007) Micro-Propagation of Cassava Plants Through the Temporary Immersion System and Hardening of Massive Numbers of Cassava Plantlets. Centro Internacional de Agricultura Tropical (CIAT), Cali-Palmira.

[18] Ubalua, A.O. and Okoroafor, U.E. (2013) Micropropagation and Postflask Management of Sweet Potato Using Locally Available Materials as Substrates for Hardening. Plant Knowledge Journal, 2, 56-61.

[19] Roca, W.M., Rodríguez, J.A., Mafla, G. and Roa, J. (1984) Procedures for Recovering Cassava Clones Distributed in Vitro. Centro Internacional de Agricultura Tropical (CIAT), Cali, 8 p.

[20] Ziv, M. (1995) In Vitro Acclimatization. In: Aitken-Christie, J., Kozai, T. and Smith, M.A.L., Eds., Automation and Environmental Control in Plant Tissue Culture, Springer, Dordrecht, 493-516. https://doi.org/10.1007/978-94-015-8461-6 20

[21] Chandra, S., Bandopadhyay, R., Kumar, V. and Chandra, R. (2010) Acclimatization of Tissue Cultured Plantlets: From Laboratory to Land. Biotechnology Letters, 32, 1199-1205. https://doi.org/10.1007/s10529-010-0290-0

[22] Aragon, C., Escalona, M., Capote, I., Pina, D., Cejas, I., Rodriguez, R., Noceda, C., Sandoval, J., Roels, S., Debergh, P. and Gonzales-Olmedo, J.L. (2006) Importance métabolique de l'amidon dans l'acclimatation des plants de bananier plantain 'CEMSA 3/4' (AAB). InfaMusa, 15, 32-35.

[23] Sahoré, D. and Nemlin Gnopo, J. (2010) Effect of Technological Treatments on Cassava (Manihot esculenta Crantz) Composition. Food and Nutrition Sciences, 1, 19-23. https://doi.org/10.4236/fns.2010.11004 